\title{
A Critical Discourse Analysis of Intertextuality and Interdiscursivity in the African National Congress (ANC)
}

\author{
Prof. Kholeka Constance Moloi
}

Vaal University of Technology, Faculty of Human Sciences, Vanderbijpark, 1900, South Africa

Email: conniem@vut.ac.za

\section{Mr Teboho Pankratius Bojabotseha}

Vaal University of Technology, Faculty of Human Sciences, Vanderbijpark, 1900, South Africa

Email: tebohog@vut.ac.za

\section{Doi:10.5901/ajis.2014.v3n4p417}

\section{Abstract}

\begin{abstract}
This paper interrogates the three ANC manifestos through intertextuality and interdisciplinarity that is grounded on critical discourse analysis (CDA). To achieve the objective of this study, the researchers draw from various scholars of CDA because it is believed that there is no single theory or method which is uniform and consistent throughout Critical Discourse Analysis. CDA refers to discourse analysis which aims to systematically explore often opaque relationships of causality and determination between discursive practices, events and texts, and wider social and cultural structures, relationships and processes (Fairclough 1993). For the purpose of this paper the focus will be on the reproduction and invocation of three African National Congress (ANC) documents: the Reconstruction and Development Programme (RDP), the Freedom Charter and the Constitution of RSA.
\end{abstract}

Keywords: Critical discourse analysis, intertextuality, interdiscursivity, African National Congress

\section{Introduction}

The main objective of this paper is a critical discourse analysis of the intertextuality and interdiscursivity in the ANC's 1999, 2004 and 2009 national election manifestos. Intertextuality and interdiscursivity are an integral part of the key concepts of Fairclough's model of Critical Discourse Analysis (CDA). Fairclough (1992:102; 1993:137) contends that texts are inherently intertextual. By that he means that texts are constituted of elements of other texts. Stated differently, in one text there is an articulation of multiple texts and voices. Texts are also interdiscursive. In other words, in a text there is an articulation of different discourses and genres (Phillips and Jorgensen 2002:73). This analysis is undertaken in terms of the key concepts of intertextuality and interdiscursivity of the manifestos. The central contention of this paper is that the three ANC texts are characterised by an articulation of multiple texts and voices (intertextuality) and different discourses and genres (interdiscursivity). On the one hand, some of these texts, voices, discourses and genres are reproduced and invoked at relevant places in the ANC texts to lend credence and an authoritative voice to the ruling party in South Africa; on the other hand, other texts and voices, discourses and genres are "censored, with some opinions not heard of and some perspectives ignored" (van Dijk 1993: 280).

Those texts and voices which are reproduced and invoked in the ANC texts include the Freedom Charter (1955), Strategy and Tactics documents (1997, 2002, 2007), the Reconstruction and Development Programme (RDP) (1994), the Constitution of the Republic of South Africa (RSA) (1996), relevant policies of the ANC, the Moral Regeneration Movement (MRM) (1997) and its appeal for the "Reconstruction and Development of the soul", et cetera (ANC 2009a). For the purpose of this paper the focus will be on the reproduction and invocation of three documents: the RDP, the Freedom Charter and the Constitution of RSA. The ANC's 1999, 2004 and 2009 national election manifestos (hereafter texts) were specifically produced for the national elections of 1999, 2004 and 2009 respectively to present "strategic directions and outlines of prospective legislation to be expected when the organisation received enough votes from the electorate to serve in government" (Scruton 1982: 352). The texts were developed against the backcloth of a socioeconomic and political context characterised by problems such as poverty, high unemployment rates and extreme social and economic inequalities (PUI) (Terreblanche 2012) within and between the various groups which constitute South 
African society. These socio-economic and political problems are rooted in South Africa's history of colonialism, racism, apartheid or segregation in terms of race, class, sexism and education, and repressive labour policies (ANC 1994: 2).

\section{Context of the Three Texts: The Constitution of the Republic of South Africa (RSA)}

The Constitution of the Republic of South Africa, Act 108 of 1996, continues to be used as a mechanism by which South Africans undertake to "build a united and democratic South Africa able to take its rightful place as a sovereign state in the family of nations" (Constitution 1996:1). Non-racialism and non-sexism are among the Constitution's fundamental founding values. In the three ANC texts considered in this paper, the Constitution is seen as providing a broad framework within which the ANC carries out its programme of change (ANC 1999:22).

\section{Theoretical Framework}

The study of the three ANC manifestos through intertextuality and interdisciplinarity is grounded on critical discourse analysis. Blackledge (2005:2) contends that there is no single theory or method which is uniform and consistent throughout Critical Discourse Analysis (CDA). CDA refers to "discourse analysis which aims to systematically explore often opaque relationships of causality and determination between discursive practices, events and texts, and wider social and cultural structures, relationships and processes" (Fairclough 1993: 135). It investigates "how such processes, events and texts arise out of and are ideologically shaped by power and struggle over power and how the opacity of these relationships between discourse and society is itself a factor securing power and hegemony" (Fairclough 1993: 135). For its enquiry, CDA does not focus exclusively on spoken and written texts. There is also "a theorization and description of both the social processes and structures which give rise to the production of a text, and of social structures and processes within which individuals or groups as social-historical subjects create meanings in their interaction with texts" (Wodak 1995: 204). Within organisations, such as the ANC, CDA focuses more closely on the question of power and control (Mumby and Clair 1997: 204). This approach to the study of language is influenced by diverse fields such as socio-linguistics, fundamental linguistics, social psychology and literary studies (Wodak 1995: 205). Even the textual analytical approaches found in CDA draw from such diverse areas as systematic linguistics, socio-linguistics, ethnography of communication, ethno-methodology, pragmatics and speech act analysis (Luke 2002: 98). Van Dijk's (1993: 279) contention that there are many ways to do critical discourse analysis is absolutely correct. Thus, this paper borrows from Fairclough's approach to CDA as it is the most developed theory and method for research in communication, culture and society (Phillips and Jorgensen 2002: 60). Fairclough (1993) provides a comprehensive definition of critical discourse analysis.

There is also no single approach to analysing the complex phenomena of intertextuality and interdiscursivity in spoken/written texts. In fact, both intertextuality and interdiscursivity have been studied from different perspectives. Wang (2008: 364) cites Culler (1981: 103), who postulates that "it is just impossible to establish the origins of all intertextual (and interdiscursive) elements in texts, as texts draw not only on other specific texts but also on anonymous discursive practices, and codes whose origins are lost". In light of this, the analysis of intertextuality and interdiscursivity becomes merely a matter of charting the multiple texts, voices, discourses and genres or identifying the sentences on which texts draw (Wang 2008: 364). However, Wang (2008: 368) believes that intertextuality, together with interdiscursivity, offers a perspective for both reading and writing texts as processes of interacting with prior texts, writers, readers and conventions. The central contention of this paper is that the three ANC texts are characterised by an articulation of many texts and voices and a multiplicity of different discourses and genres. This paper will focus on three ANC texts, namely, the Reconstruction and Development Programme (RDP), the Freedom Charter and the Constitution of the Republic of South Africa (RSA), in order to show how they are reproduced and invoked through intertextuality and interdisciplinarity.

\section{The Reconstruction and Development Programme (RDP)}

The Reconstruction and Development Programme (RDP) is a programme which was adopted by the ANC to realise its vision of the eradication of apartheid and the building of a united, non-racial, non-sexist and democratic South Africa. Mbeki (2006) is of the view that the RDP constituted the core of the election manifesto of the ANC in South Africa's first democratic elections in 1994. Hirsch (2005: 59), on the other hand, maintains that the RDP was in fact published as the ANC manifesto and, in a modified form, as a government white paper later in 1994 - a report used by government to present firm government policies and to invite opinions upon them. Its economic and political philosophy was based on 
six principles: an integrated and sustainable programme; a people-driven process; peace and security for all; nationbuilding; the linking of reconstruction and development; and the democratisation of South Africa (ANC 1994: 4-7). The six principles were translated by the ANC-led government into five key programmes: (i) Meeting basic needs; (ii) Developing human resources; (iii) Building the economy; (iv) Democratising the state and society; and (v) Implementing the Reconstruction and Development Programme - that is, its coordination and planning.

In the three ANC texts, the RDP is reproduced and invoked as an authoritative text whose principles and policies continue to guide the ANC in its struggle to change the social, economic and political conditions of South Africans for the better. The ANC's 1999 text states:

Guided by the Reconstruction and Development Programme (RDP), we have brought water, electricity and telephone lines to millions of South Africans. Houses are being built. Health and education are being made available to all (ANC 1999: 4).

In the ANC's 1999 text, the RDP remains the only relevant detailed programme to carry South Africa to freedom and social justice (ANC 1999: 22). Even Vision 2014, which is an integral part of the ANC's 2004 text, takes the RDP as its guiding document. The vision of the ANC is presented as the same vision: to build a society that is truly united, nonracial, non-sexist and democratic (ANC 2004: 6). What the three ANC texts do not reveal, however, is that the progressive goals of the RDP were in fact "abandoned one by one and new priorities were formulated in government's macro-economic policy framework - the Growth, Employment and Redistribution (GEAR) programme" (Kagarlitsky 1999) - which finally replaced the RDP in 1996 (EISA 2011; Harris 1997). In this regard, Michie and Padayachee (1997) maintain that the shift from the RDP to GEAR was in fact reflected in former State President Nelson Mandela's pronouncement in late July 1995 when he insisted that "government must abandon its obsession with grand plans and make economic growth its top priority" (Michie and Padayachee 1997: 21). Calland (2006: 4-5), on the other hand, hints at Alec Erwin's imprimatur in the controversial and fundamental shift from the RDP to GEAR It is to a consideration of the Freedom Charter that the paper now turns.

\section{The Freedom Charter}

The Freedom Charter, which was adopted in Kliptown in June 1955 (ANC 1955; McKinley 1997), played an extremely important articulating and unifying role in the struggle against apartheid (Hudson 1987: 4). It set out a list of demands grouped under the headings: (i) The people shall govern; (ii) All national groups shall have equal rights; (iii) The people shall share in the country's wealth; (iv) The land shall be shared amongst those who work it; (v) All shall be equal before the law; (vii) All shall enjoy equal human rights; (viii) There shall be work and security; (ix) The doors of learning and culture shall be opened; (ix) There shall be houses, security and comfort; and $(\mathrm{x})$ There shall be peace and friendship (ANC 1955: 1-2; McKinley 1997: 20). It became a statement of the basic human rights of all South Africans in opposition to the racist policies of the apartheid regime of the Nationalist party. However, some of its clauses (like the clause relating to economics) have always been amenable to divergent and sometimes controversial interpretations (McKinley 1997; Turok 2003). Hudson (1986: 7-8) noted not only the Freedom Charter's "brevity, simplicity and transparency of language", but also its "notorious ambiguity". It is largely this latter feature that is responsible for various and sometimes contradictory interpretations of the Freedom Charter. The most influential interpretation, for example, is one which identified the Freedom Charter as calling for the establishment of a national democratic revolution in South Africa (Hudson 1986: 6). The basis of this interpretation is a theory that characterises the social formation in South Africa prior to the 1994 democratic elections as "colonialism of a special type" (CST) or "internal colonialism". This theory, which formed the basis of an alliance between the African National Congress (ANC), the South African Communist Party (SACP) and the Congress of South African Trade Unions (COSATU), posited that the situation that obtained in South Africa was a colonial situation because all essential features of colonial domination in the imperial epoch were maintained and even intensified (SACP 1989: 18).

South Africa's colonial status was, however, of a "special type" because the colonial ruling class shared the same locality or living space with the oppressed colonial majority (SACP 1989: 18). The country was thus in a curious dichotomy of being simultaneously both a colony and an independent state. The theory further posited the "white nation" in South Africa as the colonial power or coloniser and the politically oppressed black majority as the colonised. This reality allowed the white minority, on the basis of race, to enjoy political power and privileges and a lion's share of the wealth of the country. The black majority, on the other hand, was subjected to national oppression, exploitation and a complete denial of basic human rights (SACP 1989: 18). The solution to this curious case, at least for the SACP, called for an immediate perspective (the national democratic revolution) and a long-term perspective (socialism). The content of 
the national democratic revolution was seen, in line with the theory of CST, as the liberation of the African people in particular and black people in general and, ultimately, a transition to socialism (SACP 2000: 17-23). Based on this theory of the South African social formation as CST or "internal colonialism", the Freedom Charter was seen as calling for the establishment of a national democracy in South Africa.

Regardless of how it is interpreted, the Freedom Charter continues to play a significant role in South African politics. The vision of the Freedom Charter is reproduced and invoked in the 2009 ANC national election manifesto as guiding principles which underpin the ANC's programme to transform South Africa. The plan of the African National Congress for the period from 2009 to 2014 identifies five priority areas to be tackled with "the resources of government, the vision of the Freedom Charter and the energy and commitment of our people" (ANC 2009b: 6). These priority areas include the creation of decent work and sustainable livelihoods; education; health; rural development, food security and land reform; and the fight against crime and corruption (ANC 2009b: 6). The elaboration of each of the five priority areas referred to above is preceded by a direct quotation or citation of a clause or heading from the Freedom Charter, appropriate and related to the priority area. For instance, the third clause or heading of the Freedom Charter, which states that "the people shall share in the country's wealth" (ANC 1955: 1; McKinley 1997: 20), precedes the discussion of the first priority area relating to the creation of decent work and sustainable livelihoods (ANC 2009b: 6). The ninth clause of the Freedom Charter states that "there shall be houses, security and comfort" (ANC 1955: 2; McKinley 1997: 20). An integral part of this clause is a proposition to the effect that rent and prices shall be lowered, food plentiful and that no one shall go hungry (ANC 1955: 3).

This proposition of the ninth clause of the Freedom Charter precedes the development of the priority area on food security (ANC 2009b: 8). This is what Fairclough (1992: 117) refers to as manifest intertextuality - a situation where a text explicitly draws on other texts by citing them. The following examples are demonstrative of manifest intertextuality in the ANC texts under analysis here. The same practice of reproducing and invoking relevant clauses or headings of the Freedom Charter, appropriate and directly related to the priority areas, is continued in those sections of the ANC's 2009 text which detail the plan of the ANC and practical steps to be taken to realise the plan for the period from 2009 to 2014 (see ANC 2009b: 9-14). Ramphele (2012: 19) is critical of both the Freedom Charter and the increasing public rhetoric about returning to the Freedom Charter as the supreme guiding document, especially for economic policy.

According to Ramphele (2012: 91), the Freedom Charter and other similar texts suffer from serious limitations imposed by and explained in terms of the socio-economic and political conditions in which they were produced. Stated differently, documents such as the Freedom Charter are products of their times. They were produced under a special and unique set of socio-economic and political circumstances, some of which may no longer be in existence today. For example, Ramphele (2012: 91) maintains that, contrary to popular belief, the Freedom Charter was in fact drafted by a few people in the elite leadership of the liberation movement. Furthermore, its consideration as a supreme guiding text, especially for economic policy, reflects the failure of the new dispensation to anchor economic governance within the framework and values of the national Constitution (Ramphele 2012: 91).

Harking back to the Freedom Charter, a 1955 document adopted by a particular sector of the population at a particular stage in the socio-economic and political development of South Africa, is a political game that has less to do with the ideals of that document than with positioning a segment of the ANC in the leadership struggle for the 2012 elective conference, argued Ramphele (2012: 91).

\section{The ANC's Orientation Towards Critical and Oppositional Voices}

Intertextuality has a number of orientations with regard to the notion of difference. These orientations form the basis for assessing the degree of "dialogicality" of a text, that is, the dialogue between the voice of the author of the text and other voices (Fairclough 2003: 61). According to Fairclough (2003: 42), intertextuality orientates a text to: (i) an openness to, acceptance of or recognition of difference: an exploration of difference, as in dialogue, in the richest sense of the term; (ii) an accentuation of difference: conflict, polemic or struggle over meaning, norms and power; (iii) an attempt to resolve or overcome difference; (iv) a bracketing of difference: a focus on commonality or solidarity; and (iv) consensus: a normalisation and acceptance of differences of power which brackets or suppresses differences of meaning and over norms (Fairclough 2003: 42). The paper argues that, in their intertextuality, it is the last orientation to difference which is dominant in the three ANC texts. This orientation is evident in the manner in which the ANC texts anticipate criticism of and opposition to the work which the ANC-led government has done since it assumed power in 1994. We argue that the ANC engages critical and oppositional voices and texts. This engagement takes the form of an acknowledgement of the many problems which beset South Africa under the ANC-led government and the work which the ANC-led government 
still needs to do to improve the material and non-material conditions of existence of South Africans. This is described by McKinley (2009: 2) as "the necessity to provide a degree of truthfulness when it comes to the realities and inheritances of the ANC's [19-] year rule".

The ANC's orientation to critical and oppositional voices and texts is thus different from the approach described by Hamil (2004: 703-704) as a "steady pattern of attacks". According to Hamil (2004: 703-704), the ANC attacks its critics in the opposition parties, the media and sections of the civil service. This involves various descriptions of the critics of the ANC as negative, unpatriotic, racist and, at times, even anti-revolutionary. In this regard, Ramphele (2012: 96) argues that the emotive content of the counter-revolutionary label is deliberately intended to silence dissent on pain of being marginalised as a threat to the gains made by those who fought for radical political change. In the ANC's 1999 text, the enormous difficulties that must be addressed include "inequality, lack of jobs, crime and corruption, poverty and the HIVIAids problem" (ANC 1999: 3). Contrary to Ramphele's (2012: 117) assertion that the ANC has failed to transform the socio-economic relations inherited from the apartheid state, the ANC's 2004 text maintains that "the economy has created 2 million net jobs since 1995" (ANC 2004: 5). However, the ANC immediately anticipates criticism of and opposition to the number of jobs created by acknowledging:

The number of people seeking work has sharply increased; many workers have lost their jobs; and many have been negatively affected by casualisation and outsourcing. As a result many, many South Africans do not have jobs or decent self-employment; poverty is still a reality for millions as many do not have appropriate skills, while many cannot get credit to start or improve their own businesses (ANC 2004: 5).

In the same vein, the ANC's 2009 text acknowledges that "unemployment is unacceptably high among our people [especially among] African women, rural persons and young people. There has been a growth of casualised, low-wage and outsourced jobs, contributing to the rise of the working poor" (ANC 2009b: 5). On the other hand, the ANC's 2004 text states:

Young people have benefited from the environment and programmes of freedom: from the improvements in the education system; from the outlawing of discrimination in access to professions; from the opening of opportunities in sport and culture and from the provision of electricity, water and other services to millions of households (ANC 2004: 5).

The same ANC text, however, immediately anticipates criticism of and opposition to this "achievement" by acknowledging and admitting that "... too many young people are unemployed and millions of them come from the poor households" (ANC 2004: 5). In addition to the acknowledgement and identification of the socio-economic and political problems which beset South Africa, the ANC texts provide a rationale or some form of justification for the continued existence of these problems. This includes: (i) a budget, inherited from the old order, which cannot be increased overnight; (ii) the legacy of the apartheid system, which will take time to overcome; (iii) the time needed to change apartheid policies; and (iv) powerful forces which continue to block change (ANC 1999: 5). By identifying "the growth in the number of job seekers", "casualisation" and "outsourcing" as factors which undermine progress in the creation of jobs or decent employment, the ANC is actually skilfully displacing blame and criticism of its efforts at job creation and locating it elsewhere.

In fact, the growth in the number of job seekers, casualisation and outsourcing function as indices by which, in the context of South Africa, the ANC refers to, quantifies and identifies aspects and causes of unemployment (Lakoff and Johnson 1980: 26-27). By employing the avoidance strategy (Zheng 2000), these examples of ontological metaphors focus our attention on them as causes of unemployment in South Africa and hide those factors which are inconsistent with these conceptual ontological metaphors. The effect of this is that alternative explanations of unemployment, such as those grounded within the Marxist theoretical framework, are silenced. The Marxist economist Ernest Mandel (1980) offers an interesting explanation for unemployment in societies in which capitalism is the dominant mode of production. He suggests that capitalism has an inbuilt mechanism which it uses to prevent wages from rising above a level that would endanger the valorisation of capital. This mechanism assumes a form of the expansion of the reserve army of labour, which is located in the second economy in South Africa (Mbeki 2003: 2-3), in reaction to a decline in the accumulation of capital.

The second economy (also known as the marginalised economy in the dual approach to the South African economy) is viewed by Mbeki (2004: 29) as characterised in South Africa by under-development, contributes little to the Gross Domestic Product (GDP), contains a big percentage of our population, incorporates the poorest of our rural and urban population, is structurally disconnected from both the first and the global economy and is incapable of selfgenerated growth and development. In accordance with this, Mandel's view is that unemployment is actually a structural feature inherent in the capitalist mode of production and distribution and can be explained in terms of the laws of operation of this mode of production. In can then be said that capitalism, the mode of production within which the ANC- 
led government chose to operate, creates unemployment! Space for accounts of this nature is not created in the three ANC texts analysed in this paper.

\section{Conclusion}

This paper undertook a critical discourse analysis of the ANC's 1999, 2004 and 2009 national election manifestos with a particular focus on intertextuality and interdiscursivity. The paper demonstrated that the ANC texts are characterised by multiple texts and voices. These include the Reconstruction and Development Programme, the Freedom Charter and the Constitution of the Republic of South Africa. These texts and voices are reproduced and invoked at relevant places in the ANC texts to lend credence to the ANC and to bestow on the ANC an authoritative voice in what it says are its achievements, challenges and plans in its struggle to improve the socio-economic and political lives of South Africans. The paper also showed that, contrary to some views, the ANC texts anticipate and engage those voices that are critical and oppositional to what the ANC-led government has achieved and the work it still needs to do. This engagement takes the form of an acknowledgment and identification of the enormous challenges which beset the South African social formation. In essence, the ANC texts bracket or suppress meanings and norms that are different from the dominant ones.

\section{References}

African National Congress (ANC). 1955. The Freedom Charter. [Online] Available: http://www.anc.org.za/show.phpl=72 (August 8, 2013)

African National Congress (ANC). 1994. The RDP (Reconstruction and Development Programme): A policy framework. Johannesburg: Umanyano.

African National Congress (ANC). 1999. 1999 Manifesto. [Online] Available: http://www.anc.org.za/elections/manifesto/manifestotext.txt (September 20, 2013)

African National Congress (ANC). 2004. 2004 ANC Manifesto. [Online] Available: http://www.anc.org.za/elections/ 2004/manifesto/manifesto.html (September 20, 2013)

African National Congress (ANC). 2009a. Elections 2009a: ANC Manifesto Policy Framework. [Online] Available: http://www.anc.org.za lelections/2009/manifesto/policy-framework.html (September 20, 2013)

African National Congress (ANC). 2009b. 2009 ANC Manifesto. [Online] Available: http://www.anc.org.za/elections/ 2009/manifesto/manifesto.html_(September 20, 2013)

Blackledge, A. 2005. Discourse and Power in a Multilingual World. Amsterdam/Philadelphia: John Benjamins.

Calland, R. 2006. Anatomy of Power. Who holds the power? Cape Town: Zebra Press.

Electoral Institute for Democracy in Africa (EISA). 2011. South Africa: The presidency of Nelson Mandela (1994-1999). [Online] Available: http://www.eisa.org.za/WEP/souoverviews8.htm (August 18, 2013)

Fairclough, N. 1992. Discourse and Social Change. Cambridge: Polity Press.

Fairclough, N. 1993. Critical discourse analysis and the marketisation of public discourse: The universities. Discourse and Society, 4: 133-168.

Fairclough, N. 2001. Language and Power. England: Pearson Education.

Fairclough, N. 2003. Analysing Discourse: Textual analysis for social research. London \& New York: Routledge.

Hamil, J. 2004. The elephant and the mice: Election 2004 and the future of opposition politics in South Africa. The Round Table. The Commonwealth Journal of International Affairs, 93:691-708.

Harris, L. 1997. Economic objectives and macro-economic constraints. In J. Michie and V. Padayachee. (Eds.). The political economy of South Africa. Policy perspectives in the late 1990s. London: The Dryden Press, pp. 91-100.

Hirsch, A. 2005. Season of Hope: Economic reforms under Mandela and Mbeki. Scottsville: University of KwaZulu-Natal Press.

Hudson, P. 1986. The Freedom Charter and the Theory of National Democratic Revolution. Transformation, 1: 6-38.

Hudson, P. 1987. On the National Democratic Revolution: A reply to Cronin. Transformation, 4: 54-59.

Kagarlitsky, B. 1999. New Realism, New Barbarism: Socialist theory in the era of globalisation. London: Pluto Press.

Lakoff, G and Johnson, M. 1980. Metaphors we live by. Chicago and London: The University of Chicago Press.

Luke, A. 2002. Beyond sciences and ideology critique: Developments in critical discourse analysis. Annual Review of Applied Linguistics, 22: $96-110$.

Mandel, E. 1980. Historical materialism and the capitalist state. [Online] Available: http://www.marxists.org/archive/ mandel/1980/xx/hismatstate.htm (November 20, 2012)

Mbeki, Thabo. 2003. 'Letter from the President: Bold Steps to end the 'two nations' divide', ANC Today , Vol. 3, No. 33. [Online] Available: http://www.anc.org.za/ancdocs/anctoday/2003/text/at33.text_July 21, 2006)

Mbeki, T. 2006. Nelson Mandela Memorial Lecture. University of the Witwatersrand, July 29.

McKinley, D. 1997. The ANC and the Liberation Struggle: A critical political biography. London: Pluto Press.

McKinley, D. 2009. South Africa: A critique of the ANC and Cope election manifestos. [Online] Available: http://links.org.an/node/953 (July 30, 2013)

Michie, J and Padayachee, V. 1997. South Africa's transition: The policy agenda. In J. Michie and Y. Padayachee (Eds.). The political 
economy of South Africa's transition. Policy perspectives in the late 1990s. London: The Dryden Press, pp. 9-26.

Mumby, D.K. and Clair, R.P. 1997. Organizational Discourse. In T.A. van Dijk. (Ed.). Discourse as social interaction. London: Sage, pp 181-205.

Phillips, L and Jorgensen, M.W. 2002. Discourse Analysis as Theory and Method. London/Thousand Oaks/New Delhi: Sage.

Ramphele, M. 2012. Conversations with my Sons and Daughters. South Africa: Penguin Books.

South African Communist Party (SACP). 1989. The Path to Power: Programme of the South African Communist Party, as adopted at the seventh Congress.

South African Communist Party (SACP). 2000. Manifesto of the South African Communist Party: Building workers' power for democratic change. Johannesburg.

Scruton, R. 1982. A dictionary of Political Thought. London: Pan Books.

Terreblanche, S. 2012. Lost in Transformation: South Africa's search for a new future since 1986. Johannesburg: KMM Review.

The Constitution of the Republic of South Africa, Act 108 of 1996.

Turok, B. 2003. Nothing But the Truth: Behind the ANC's struggle politics. Johannesburg and Cape Town: Jonathan Ball Publishers. Van Dijk, T.A. 1993. Principles of Discourse Analysis. Discourse and Society 4(2): 249-283.

Wang, W. 2008. Intertextual Aspects of Chinese Newspaper Commentaries on the events of 9/11. Discourse Studies, 10(3): $361-381$.

Wodak, R. 1995. Critical Linguistics and Critical Discourse Analysis. In J. Verschueren, J.O. Ostman and J. Bommaert (Eds.). Handbook of Pragmatics Manual. Amsterdam/Philadelphia: John Benjamins, pp 204-210.

Zheng, T. 2000. Characteristics of Australian political language rhetoric: Tactics of gaining public support and shirking responsibility. [Online] Available: http://www.imi.se/intercultural/nr4/zheng.htm (July 30, 2013) 
